Anne Mette Fisker-Nielsen

\title{
The Making of
}

\section{Representations of the Religious Adherent Engaged in Politics}

\begin{abstract}
Anne Mette Fisker-Nielsen, $\mathrm{PhD}$ (SOAS), is a Teaching Fellow at SOAS, University of London. She has written a book entitled Young Soka Gakkai Youth and Komeito: Religion and Politics in Contemporary Japan (Japan Anthropology Series; Routledge, forthcoming), which is based on her PhD thesis. Her interests are in Japanese politics and Japanese new religious movements, anthropology of politics, religion, and civil society, and social theory.
\end{abstract}

\section{SOAS, University of London}

Dept. Sociology and Anthropology Russell Square London

UK

af3@soas.ac.uk

\begin{abstract}
In this paper, I present two ethnographic examples of young Japanese who as members of the lay Buddhist organization Soka Gakkai in Japan support the political party Komeito. I highlight that concord about interpretations of meaning between the anthropologist and the interlocutors makes for different understanding of motivation and subsequently for different representations. While the anthropologist's work in most cases remains an ethnographic account written by the researcher, fieldwork and personal interaction with people who are regarded as interlocutors rather than subjects of study help to make the subject community, not the observer, the people who set the criteria for representation. This does not exclude a critical approach to the social phenomenon researched, but a closer understanding of the paradigmatic position of the people whom one writes about can, with careful reflection, help to overcome the particular biases of structural objectivism. While this position may have its own biases, the starting point is the participation of the anthropologist in inter-cultural discourse with the people studied, rather than an authority who has the last say on the matter. This is looking at social phenomena from the level of meaning, aiming to understand social tendencies to action rather than from a position that asks questions about facticity from a deductive approach about an abstract empirical reality.
\end{abstract}

Keywords: issues of representation; political participation; religion and politics; Soka GakkaiKomeito; youth in Japan. 
from a cross-cultural perspective, the rationalist framework constitutes local native theory and forms a part of the object of study (Ouroussoff, 2001: 38)

\section{Introduction}

My research focuses on young Japanese who, as members of the Buddhist organization Soka Gakkai (value-creation society), support the political party Komeito (Clean Government Party), a party that grew out of it in 1964. Soka Gakkai International (SGI) has some twelve million members worldwide, ten of which are in Japan. It is the biggest out of a number of lay Buddhist organizations that follow the thirteen-century monk Nichiren (1222-1282). Apart from many religious activities, members often engage in civic and cultural activities, hosting exhibitions on nuclear disarmament or environmental protection, activities that aim to raise awareness about the plight and issues that face peoples of the world. Such social objectives are part of what religious practice means to people in Soka Gakkai. However, in Japan, what attracts most public attention are not these activities but Soka Gakkai's controversial involvement in supporting the political party Komeito. The two organizations are institutionally separate legal entities; Soka Gakkai sees itself as in a similar position to a labour union that provides organized electoral support to the party it favours. However, despite a political agenda that is social democratic and to the centre in politics, Soka Gakkai members' motivation for this political participation is often judged and regarded as questionable. It is often portrayed as a search for political power to protect the Soka Gakkai itself and further the influence of its long-term spiritual leader Ikeda Daisaku. The political activism of Soka Gakkai members is likely to continue to be portrayed as controversial as long as they direct their political objectives primarily into supporting a single party. While not all Soka Gakkai members canvass or vote for Komeito, the majority of active members (probably about half of the Soka Gakkai membership) are likely to continue their support into the future. To understand why such support for Komeito is likely to be forthcoming despite the controversy it creates requires an in-depth study of the subject. I here explore the motivation for this relatively unanimous support for one political party by a religious organization. I argue that though it may seem from a structural or deductive approach that Soka Gakkai members are voting "en masse" as it were, this does not mean we can so easily conclude that they do not exercise independent political judgment. Nor does it mean we can conclude that their political activities are therefore non-political, that is, as if they simply support Komeito out of loyalty to Soka Gakkai, independent of political agenda. A political science perspective or deductive approach relies heavily on a priori definitions of politics, such as who gets what, when and 
how (Lasswell, 1950). Politics at this level is essentially analysed in terms of the power acquired, which, however, does not necessarily mean there is a correlation between relatively unanimous support for a political party by a religious organization and unthinking people engaged in non-independent and even non-political activism who are used in order to achieve a power based for its own sake. To explore this, it is necessary to direct our attention to the notoriously difficult subject of motivation, something that was the starting point of Weber's sociology, and that distinguished him from Durkheim's deductive "social fact" level of analysis on which political scientists often conclusively seem to draw. I base my conclusions on firsthand participation in and observations of grassroots political activities among young Soka Gakkai members spanning the general elections in 2003 and 2004, which were the focus of my PhD fieldwork, as well as on post-PhD fieldwork research during the election of 2009. This research is based on hundreds of conversations, more than fifty interviews with Soka Gakkai members, and Soka Gakkai and Komeito officials. Komeito, a centrist party, for ten years (1999-2009) joined hands in a coalition government with the Liberal Democratic Party, or LDP, the conservative political party that has been in power in Japan almost uninterruptedly since WWII. They lost the August 2009 election for the Lower House.

The discussion revolves around three main issues: firstly, whether the claim to religious motivation should be accepted at face value especially as religious adherents engage in politics. Alternatively, one could argue that politicians are always essentially power seeking, which is seen as not squaring up with religion very well. The common sense assumption and "secular" critique is that political motivation based on religious beliefs and practice is somehow improper or abnormal. I address this issue through a kind of insider/outsider distinction (what political supporters claim, what outside observers claim, what "inside" observers claim). Related to this is the Japanese (or Japanese media) ambivalence or even hostility to religious groups' involvement in politics. This ambivalence revolves around the secular critique of religion, and around Japan's particular history of State Shinto. A third issue is the way my own relative co-religionist subject position (as an SGI-member in the UK) complicates the insider/outsider distinction, not least because it predisposes me to accept some irreducible component to religious experience and the motivations that stem from it. In other words, I am less likely to accept the ambivalence or hostility towards this religion felt by those whose views I report ethnographically here. I argue that one's paradigmatic position (see Scholte, 1980) creates the "common sense" that underlies different positions and subsequent interpretation, however "distant" one's outsiderhood in connection to the social phenomenon under study. This will always result in interpreting someone else's

(c) Equinox Publishing Ltd 2011.

\section{equinoxonline}


social world, and in this case political objectives, at least partially from that perspective. I further argue that compared to a deductively perceived "reality" of social facts (in the Durkheimian sense) fieldwork based on empathetic understanding and interaction is bound to provide a different level of analysis. In the deductive approach social phenomenon is defined a priori with people fundamentally viewed as objects in need of accurate categorization. There is little recognition that "truth" is also a social practice, the stance the anthropologist tends to take. In the latter case, subjects are diverse individuals with whom the anthropologist enters into an inter-cultural discourse that seeks a more in depth understanding of social reality. Each individual is never the same as the person next to them, and always experiences the social world from his or her subject position. Even within certain general patterns found within the same religious or political beliefs, a subject position is unique. In this sense, the anthropologist's analysis is seen as drawing on an amalgamation of a polyphonic (Bahktin) social reality. This is not to say that the anthropologist can avoid or wants to avoid some forms for abstractication and generalization, but such conclusions are made from a thoroughly grounded and inductive approach.

The difference between the two positions is one of degree in which the first more decisively makes the observer the authority while the other tries inductively to make the subject community the criteria for representation, a position recognized as never wholly tenable. The core activity is still social description of someone else, a position that remains problematic however inductive the level of analysis. While standards of objectivity bear the clear mark of history so does the process of recognizing this fact. In Discourse and Language (1976), Foucault discusses how the production of truth is to be understood as statements capable of being taken seriously as true or false. This epistemological dilemma is central to anthropological knowledge, and central to understanding the power of the homogenizing discourses that surrounds the case under study. Moreover, my concern here is also focused on the anthropologist as "half-native," a position that emphasizes the epistemological tensions between observed/observer, tensions that therefore do not so easily map onto the insider/outsider distinction, or onto the secular/religious division of modern social science disciplines. To explore "the inescapable ambivalence and ambiguity of subject-positions" (Battaglia, 1999: 123), I focus on the way the agency of young people who are members of a new religion in Japan is interpreted. Although the Soka Gakkai movement is very successful in Japan, members are widely perceived to be somehow submerged in "mass" or unthinking behaviour, especially in their support for Komeito. 


\section{Political Representations and New Religious Movements in Japan}

When it comes to attempts to depict "Japanese" engagement (or lack thereof) with their political world, mono-cultural and abstract notions of national identity are often used. Much political science writing on Japan has emphasized the forces of dominant political ideologies, and the binding character of normative constructions of the Japanese citizen (e.g. Curtis, 1988; Johnson, 1995; Van Wolferen, 1989; Hoye, 1999; McVeigh, 1998; Abe et al., 1994; Scheiner, 2006). Stressing the homogeneity of social groups that bolster prevailing relations of power in the modern Japanese nation-state, Japan has been depicted as a society where social experience is determined by social structure to such an extent that it squeezes out much individual agency. The typical epistemological problem of confusing a normative ideal with the reality, or ideologies with practice (Goodman and Refsing, 1992; cf. Roberts, 2005) too quickly turns to generalized arguments. In this way, the individual fits rather neatly into a Radcliffe-Brownian structural-funtionalist model. In Japan, the view of civil society has been largely one of apathy with Japanese democracy as something of a farce where the Liberal Democratic Party rule and voters having little say in, understanding of or interests in securing democracy proper. People who do engage in politics are usually part of support groups (koenkai) that are seen to be primarily clientelist in kind with supporters motivated by selfinterest within a political system largely ruled by pork-barrel politics (Lipson, 1993; Schaede, 1995; Christensen, 2000; cf. Stockwin, 2008). The potential variety of perspectives and complexity of experiences of people who supposedly exist within these wider social discourses are at best obscure.

Few studies have focused on what actually goes on at the grassroots level. My focus on young people arose as an attempt to explore the widely perceived notion that Japanese youths in particular are politically apathetic, lacking in agency within a wider social system that is largely antithetical to individual choice and creativity. Recent anthropological studies have found a mixed picture (Mathews and White, 2004). Some conclude that young people's lived experience is either so socialized that they cannot but reproduce an overly controlling adult world. Other young people have had such an awful experience of growing up that they end up isolated or dropping out of the system all together, while others cope better and successfully create new types of social networks (Kotani, 2004; Sakurai, 2004; Kobayashi, 2001; Nakano and Wagatsuma, 2004; White, 2004). Yet, there are few if any examples of young people being involved with organized activities that address common social concerns. Contrary to this, I highlight instances of young individuals who canvass for a party that attempts to address wider political issues such as adequate

(c) Equinox Publishing Ltd 2011.

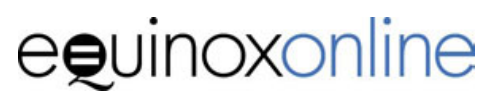


welfare provision, environmental protection, human rights and international peace. A further caveat is that these young people are not to be found among the consumers of popular culture whom some describe as changing the social landscape of Japan, but in a new religious organization. Members of such organizations have not previously been considered in such positive terms.

After 1945, when State Shinto ceased to be a state-driven public civil religion a pluralism of independent religious organizations emerged. While Japan was seen to become democratic, religion continued to flourish (Reader and Tanabe, 1998). Japanese modernity and post-industrial society have not coincided with the decline of religion, the main thrust of the secularization theory (e.g. van Bremen, 1995). While so-called "traditional" Buddhism and Shinto continued to exist, the number of people belonging to lay-oriented new religions, or shinshūkyō, grew tremendously and they were also the most active in community activities (see Earhart, 1984; Inoue et al., 1996; Hardacre, 2003, 2004; Shimazono, 2004). Whether we can continue to refer to such organizations as "new" has been debated, but it was a term that came into parlance in Japanese scholarship in the 1970s (Reader, 2005). This term refers to certain sectarian developments within Shinto and Buddhism that began mostly some time in the nineteenth or early twentieth centuries. Indeed, a group could have existed for two hundred years and still be referred to as "new" (see Shimazono, 2004: 234, table 12.1). The NRMs scholar Hardacre (2003) estimates that around one quarter of the Japanese population belong to a new religion; another scholar, Shimazono (2004), believes it to be somewhere between ten to twenty percent. Soka Gakkai, established in 1930, is today the largest of these organizations.

These religious organizations serve the public good in various ways. They run schools, hospitals, orphanages, homes for the elderly, and museums; they organize concerts, exhibitions, collect aid for disaster relief, and volunteer in a multitude of ways. Some of them such as Soka Gakkai are active in a variety of peace activities that they often coordinate with the UN as NGOs. For instance, Soka Gakkai has been involved with a variety of anti-nuclear activities for close to half a century, and is still actively involved in furthering the NPT. However, they do not enjoy much public trust in Japan (Hardacre, 2003; Ishii, 2000). Murō (2000) shows how the traditional print and broadcast media refrain from reporting any good news about religion or even legal verdicts favourable to religion. Hardacre (2003) notes that the lack of trust in new religious organizations is primarily due to a politicization of public opinion regarding religion, as well as the emergence of so-called "new-new" religions, religions that appeared from the 1970s onwards (cf. Reader, 2005). One of these in particular, the Aum Shinrikyō, had fatal consequences for the public in the mid-1990s (e.g. Metraux, 1999). This coincided with a time when political parties

\section{equinoxonline}


belonging to the opposition, of which Komeito was a major force, were enjoying increasing public support. One political tactic on the part of the LDP to undermine the opposition was to establish links in the public mind between Soka Gakkai and Aum (LoBreglio, 1997; Yuki, 1997; Kisala, 1999; Hardacre, 2003).

Furthermore, contrary to the West (Europe and North America), belief in one religion at the exclusion of belief in others conjures up notions of a too intense religiosity, a religiosity that in other cultural context would be taken as a given. In the West, religious syncretism generally is seen to be the province of dangerous sects or new age movements. Japan, on the other hand, has a long history of religious syncretism, or religious co-existence even within the same temple or shrine premises. Choice of one religion somehow is associated with the experience of State Shinto, which brings back unwelcome memories of a time when one religion was supreme. The tradition of religious syncretism makes the choice of one religion at the exclusion of others seems unnatural or un-Japanese, a kind of religious "exclusivism" that is associated with Soka Gakkai in particular (see Nakamaki, 2003). This feeds into other representations of these organizations as typical Japanese vertical organizational structures that foster absolutism and a strong collectivism. Some of the most influential studies of Japanese political culture undertaken by Kunio Yanagida and Ruth Benedict, and from Masao Muruyama to Chie Nakano have shown the Japanese to fit such kind of homogenous social groups. Interpreting new religious organizations in a similar fashion by focusing on supposedly manipulative social structures, Soka Gakkai has even been described as bordering on fascism (Davis, 1991). Nakane's famous depiction of new religions as mirroring “Japan's former military system" in which "the astonishing success of these new religious groups...seems to be attributable mainly to their system of vertical organisation" (1998 [1970]: 61) still widely informs basic assumptions about Soka Gakkai in Japan.

Soka Gakkai's seemingly fanatical proselytization in the 1950s and 60s coupled with its increasing political influence (White, 1970) contributed to this image of danger in its early days, an image that often remains the starting point for analysing Soka Gakkai's political involvement. Many religious groups in Japan support political parties or candidates (for instance the rightwing Shinto Political Federation, see Hardacre, 2005) although little data on this is forthcoming, but suspicion, if not caricature, of Soka Gakkai's support for Komeito has remained the order of the day as shall be seen in the next section. Its success in the religious and political world has therefore been difficult to comprehend, and usually attributed to superior organizational skills. Its organizational structure is undoubtedly a contributing factor, but this still does not account for why people vote for Komeito, or why people are attracted to Soka Gakkai.

(c) Equinox Publishing Ltd 2011.

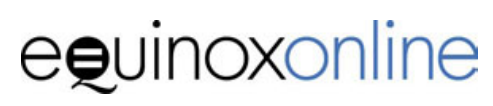




\section{An Obedient Foot Soldier or a Participating Citizen}

The first ethnography is of a press conference at the Foreign Correspondence Club of Japan where Takao Toshikawa, a famous political commentator and journalist, explains Soka Gakkai members' political activities at a publicly overwrought time three days prior to the 2003 general election. Attending this press conference turned out to be an interesting start to my fieldwork because Soka Gakkai members' support for Komeito was represented as the determining factor in the election. Toshikawa, regarded by some as an astute political commentator, started by announcing in English that today he would be speaking through an interpreter because what he was going to say was too important to risk any misunderstanding. Switching to Japanese, he announced his predictions for which party would take how many seats. It soon became clear from his words that a worrying situation was developing: namely the increasing influence of Komeito and thereby Soka Gakkai, the millions of members of which, according to Toshikawa, do exactly what their leaders tell them. "Why do I stress the Komeito and Soka Gakkai factor?" Toshikawa asked, before outlining how the ruling Liberal Democratic Party was losing support from its traditional support groups due to structural reforms enforced by the then prime minister Junichiro Koizumi, because "after the election, power will depend day-by-day on the support of Komeito and Soka Gakkai."

Two thirds of his speech appeared to be devoted to talking about the "Komeito/Soka Gakkai factor." After he had finished his speech, someone from the press asked why Toshikawa kept stressing the influence of absentee voters. His answer returned to the "primary factor." "There are about 650,000 absentee voters, and $60 \%$ of those come from Soka Gakkai members. People in the LDP and Soka Gakkai know this and can mobilise this number." There was a follow-up question: "Why would they want to vote absentee - are you trying to say that Soka Gakkai obtain absentee ballots illegally?" Answer: "it is important to realise that Soka Gakkai has very good co-ordination in the districts and that they start half a year earlier to prepare for the election. They have members moving official residences. The Soka Gakkai analyse and co-ordinate with the LDP. Where the LDP is weak, they mobilise Soka Gakkai accordingly."

The question remained hanging in the air - were they or were they not obtaining absentee ballots illegally. Just as I was wondering if Toshikawa was going to be more specific as to why the Komeito/Soka Gakkai factor was such an unwelcome influence in politics, the second question to that effect came: "What specific influence does the Komeito/Soka Gakkai have on policies?" To which Toshikawa answered: "I am by no means a foot soldier of the Soka Gakkai. The LDP and Komeito differ in basic policies. Komeito is for big government, whereas Koizumi is 
for small government. The Komeito has the backing of Daisaku Ikeda, who has stated that Komeito must remain in the coalition, that they must stay to maintain political power. It is possible that in November 700 Self Defence Forces will be sent to Iraq. Within the Soka Gakkai there are many subgroups that are against this, but Soka Gakkai has made the decision in order to stay in power. Information about this comes from NHK, Yomiuri, Asahi and internal documents from Soka Gakkai."

Then a curious thing happened. At hearing Toshikawa's reply, the journalist from the Financial Times who had asked the question rose to his feet again to make a stammering apology saying, "I by no means meant to say that you were a foot soldier of the Soka Gakkai," although it was obvious that no such thing had been implied from his question. Toshikawa in his position as the guru of political analyses coupled with his many articles about what seemed to be his pet subject, Soka Gakkai and Komeito, hardly made his own position ambivalent: he was by no means a secret admirer. This moment was penetrated with the "commonsensical" view that Soka Gakkai as a religious organization was a negative social force trespassing into the political world. The felt need not to appear to be questioning this common sense had been so overwhelming that an independent journalist rose to his feet to apologize for an opinion that he had not even expressed. No one laughed and the atmosphere was tense. The common sense that the political support for Komeito constitutes the activities of unthinking, religious foot soldiers, instructed by authoritative social hierarchies of leadership is a view that resonates with other recent works on the topic (Eto and Hichiri, 2003; Yamada, 2004; Sado, 2005).

The second ethnography looks more closely at some of the young "foot soldiers" who canvass for Komeito. Nami was a twenty-three year old law student, a devoted Soka Gakkai member and from Okinawa originally. She was also an active Komeito supporter. She happened to be looking for a roommate and a part-time job when I arrived in Japan in October 2003, which meant that I could stay with her, and she looked after my seven-month-old daughter. We became good friends as well. As the upcoming election in November was approaching Nami was out most nights meeting with other young women who were also studying at Soka University in Hachioji, Tokyo, where they lived. These young women, all in their early twenties had decided to meet up to encourage each other to call up potential voters and to try to get them to vote for Komeito. At these small gatherings, the young women always first chanted together - repeating at a fast and rhythmic pace the phrase Nam-myoho-renge-kyo, which they took to have been declared by Nichiren as the way to develop an inner directed, spiritually rich, and compassionate state of mind, something they referred to as Buddhahood. After chanting, from which they clearly felt invigorated, they began telephoning potential voters - friends, acquaintances,

c Equinox Publishing Ltd 2011.

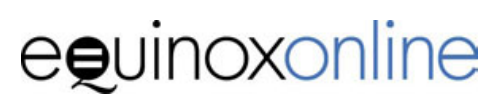


and old school mates. Most of these young women were, like Nami, from places other than Hachioji - Niigata, Nagoya, Kyoto, Hiroshima - living in Hachioji because they were Soka University students. They were calling people in their hometown to try to get them to vote for the Komeito there. Conversations with potential voters lasted anything from one minute stammering out the reason for why they had called, to half-hour-long conversations about politics, the importance of voting to have a say, and various social and political issues of the day.

Nami was active not only in her religious activities but also in trying to achieve political objectives through her support for Komeito. The political objectives were centred on a political agenda of improving social welfare, education, environmental protection, and other issues that could best be described as social democratic. Upon our return from the nightly gatherings, Nami and I often discussed late into the night about Komeito policies, about Soka Gakkai, about the complexity of the relationship between the two and about Daisaku Ikeda, the long-term spiritual leader of Soka Gakkai whom they call Sensei, or mentor/teacher. Nami was clear about her objectives and reasons for supporting Komeito, as most of them seemed to be when they discussed Komeito policies compared to other parties. They hoped, and mostly trusted that Komeito tried its best to influence politics towards creating a more humane society, a society that stressed social welfare, equality, and peace. When asked about the purpose of being involved in politics, their answers reflected what they had learned from Ikeda's writings, namely, that Komeito was and should be a party that worked for the betterment of society as a whole. They expected Komeito politicians to have personal integrity, to be free of corruption, and to work on the side of people who were struggling with daily life. Young Soka Gakkai women in Nami's area would often pass by and I participated in many discussions, conversations during this time that always returned to the political issues of the election. It was a lively place to live and engage in "after hours" participant observation (Gellner and Hirsch, 2001: 7).

Despite Nami's all-out support for the party, she was by no means an uncritical supporter. The conversations often turned to the inherently problematic nature of supporting a political party, especially as a small party in a coalition government with a much more powerful partner. How could supporters be sure that politicians were trying their best to influence policies in a desired direction without compromising too much with the LDP? Such negotiations were not transparent and they had to take Komeito's word for it. Nami knew that being part of the government as a small coalition partner was much less straightforward than being an opposition party where stating ideals were their main political drive. The issue of being a religious organization that supports a political party was less of a problem in

\section{equinoxonline}


theory as she knew they had sound political objectives. However, there were inherent difficulties in the dynamics of uniting to support one party, and some young people were not interested in politics at all. However, the politically active young people I spoke to had political ideals that resonated strongly with creating a fairer and more humane world. They knew that organized action was needed to achieve such objectives, and that this was the challenge, not their ideals. Uniting to support one political party had its difficulties. Moreover, given that Soka Gakkai members see their own actions as the vehicle for creating a just and compassionate society for which support for Komeito was an extension, political compromises facing the party as part of the coalition were not always easy to accept. Sometimes the ability of Komeito to stand up for its proclaimed ideals of social welfare, peace, and environmental protection - social pursuits that clearly arose from their religious values - was questioned. Theirs was an ethical approach to life that complicated their understanding of the relationship between self and other, between themselves and their political objectives rather than simplified it. Religion was not a commitment to a moral code, but an ethical way of being in the social world. Practically speaking, when political decisions seemed too contradict Komeito's stated objectives they would seek the answers either from senior leaders or by writing directly to Komeito politicians to voice their objection or to get them to explain their decisions. Politicians did not feel far away, also because of the many (some 3000) local Komeito politicians to which people can turn relatively easily. Yet, despite this local network that aimed to bring the voice of people to the arena of politics, not all Soka Gakkai members voted for Komeito. The precise number of such individuals is difficult to ascertain, but there were clearly also a significant number of young Soka Gakkai members, probably about half who, like other youths more generally, were not interested in politics. Moreover, some vote for other parties because they work for companies that support for instance the LDP. Komeito lost nine seats in the August 2009 Lower House Election, a loss which can at least partly be attributed to former Komeito supporters switching to the then popular Minshutō. At one level, Toshikawa's prediction had been apt; the LDP had become increasingly dependent on the support of Soka Gakkai members, a support that was not enough to sustain it by 2009 .

\section{Representing the "Abnormal" Religious Adherent as the Engaged Citizen}

While a political scientist may be seen to be describing facts, he or she arguably less clearly accounts for the way motivation is interpreted. The different way in which I understand the same young people's motivation and political action has to do with 
my methodology and with insider knowledge. As someone who has practised the Buddhism expounded in Soka Gakkai for the past twenty years mostly in Hong Kong and the UK, but also three years in Japan, I find personal agreement with the ethical and social objectives of the organization, objectives which I take for real and do not see as mere rhetoric. I am aware that the kind of meaning structures the philosophy provides because I am also aware of the way they have restructured my own worldview in subtle but profound ways. I am not Japanese, however, and I have only lived in Japan as a student of Japan. Still I can relate to the way my informants engage with the challenging process of actively attempting to take action for broader social issues and from an ethical position of mutuality. Evans-Prichard made the point, highlighted by Burton (1983: 176) that, "If one disregards the local questions, nothing is explained or understood other than the premise of the particular theory adhered to." While we may question the extent to which EvansPrichard himself overcame the problem of structural objectivism, this point has continued to be important in anthropology. When asked, political scientists will comment that because Soka Gakkai does not elect its leadership it is not democratic; by extension, the democratic nature of its political support for Komeito is questionable. By comparison, many non-religious organizations, voluntary and otherwise, and most businesses do not elect by popular mandate their manager or director, but they are seldom by default categorized as totalitarian or undemocratic. Neither is this fact given as the independent variable that explains their success. I do not argue that by simply removing what appears to be "rationalist" prejudice against religious organizations a non-totalitarian group is revealed whose political participation is always welcome. This is obviously something that needs to be established on a case-by-case basis.

I also need to reflect on the "knowledge" that predisposes me to accept some irreducible components to religious experience and the motivations that stem from it, as it becomes part of my method. My informants' knowledge that I was an SGI member allowed me to critically observe and question people without them feeling defensive. This was because the standard of judgment in many ways was their own. I was the implicitly trusted stranger who the interlocutors knew as someone who lived her personal life with similar social objectives as they. This in return engaged us in a discussion about the complex process of social transformation they saw themselves as part of, a social transformation that for them included support for Komeito. Support for a political party was something that made this process a lot more complex and contentious but it was driven by a desire to contribute to greater social transformation. For example, people who had heard about my interest in the dilemma that I imagined SGI members would have when Komeito, as a 
coalition partner to the LDP, had seemingly supported the invasion of Iraq in 2003 were eager to meet me and verbalize their apprehensions about this decision. Had I not been an SGI member, I doubt they would have talked quite so frankly about these difficult political issues because in the media they were being represented as having given up on their ideals of peace through continuing to support Komeito in order to maintain political power for its own sake. The situation was a lot more complex than that as I discuss elsewhere (forthcoming). In this way, my coreligionist subject status made Soka Gakkai members who canvassed for Komeito approach me without assuming I harboured a huge amount of suspicion regarding the "real/suspect/hidden" motives of both Soka Gakkai and Komeito. For me the starting point was not that there was something "wrong" with the fact that these individuals' political activism is being directed, perhaps comparatively speaking, rather unquestioningly to support one political party. Such relative unanimous support for a political party has been more the norm than the exception in Japan, where voting according to one's professional status group or according to the company for which one works has until more recently characterized Japan's political culture. For instance, bigger companies or professional groups such as the Japan Medical or Dentist Associations have traditionally supported the LDP. This tendency can be seen at the other end of the political spectrum where for instance certain cooperative hospitals expect employees to campaign on behalf of the Communist party. Old social and economic networks and collectivist authoritarian value preferences remain important, but increasingly less so as has been evident with the personalization of politics and the increase in non-affiliated voters (e.g. Inoguchi, 2009). "Collectivist" voting patterns may come across as an anomaly against political activism in the broader and freer sense. Yet, young Soka Gakkai members' political activism does not reflect obedient masses of followers whose political influence is undemocratic. Neither is it an expression of the desire for one religion to reign supreme. No political engagement is perfect, but the case under study points to a need to address the hegemony of intellectuals and the media that represent religious persons, a hegemony that allows political commentators to present themselves as objective and as people who decisively know what is going on.

No one should glance easily over the fact that the anthropologist, and arguably the political scientist as well, is a flawed and biased instrument of cultural translation. For the anthropologist this tension is central because knowledge is based on interaction with those one is writing about. This interaction usually takes the form of empathic understanding, which does not mean the anthropologist is always sympathetic, but there has to be some kind of trust between observed and observer. This does not exclude a critical perspective towards the subject under study, but it

(c) Equinox Publishing Ltd 2011.

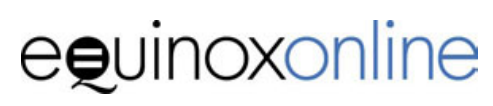


produces a different kind of critique that is derived from a different type of observer/observed relationship, a relationship that does not automatically become more objective the greater the distance between the two. I would argue that a closer relationship between the experience and the rational account of it need not be less objective, indeed it could be more objective, although again, not by default. "Insider" objectivity is likely to be different from the more obvious "outsider" objectivity where the interpellation of subjects are made prominent to account for the production of subjects proper in a particular objectivist form. Any "gaze" is created and presents its own inherent political and ethical dimensions as argued by Foucault (e.g. 1979). Yet, a perspective can only be problematized if a reflexive account of the subject position of the observer, whether an insider or outsider, coreligionist or non-coreligionist is observed. (This is done usually with the help of others, in my case my supervisor during my PhD years).

The different ways of viewing Soka Gakkai's support for Komeito as discussed in this article touch on the issue of reconciling theory with ethnography. A reductionist theory through which religion is viewed as presented by political scientists and the media contrasts with my ethnography and firsthand research, which some may accuse of being an internal phenomenological perspective. Theory here is seen as the product of a reductionist point of view and ethnography as a personalized point of view (Kunin, 2006). However, I have argued that both are "personalized" views to some extent and are dependent upon how motivation is interpreted. In contrast to the views presented by the example of Toshikawa, my observations reveal a religious movement that engages in associational life, with the objectives of creating a good society, and as people who have conversations in the public sphere about public issues. The particular canvassing for Komeito reflects a belief and trust in politicians who are seen as political representatives that attempt to make broader individual and societal interests their objective. Support does not stem solely from personal loyalty to Soka Gakkai, although there are elements of that as well. The young people who support Komeito believe in a humanistic philosophy and engage in a religious practice that focuses on inner and outer ethical change. Individuals are relatively autonomous thinkers, as much as any of us, but are united by a deeper commitment to changing themselves and to furthering humanitarian issues in society. However imperfect these processes may be, they are the very stuff that makes the objective standards we set for democracy viable. Contrary to expectations that arise from representations of obedient flocks of "foot soldiers," these young people attempt to appropriate the very democratic ideals we associate with democracy despite the fact that the religious organization to which they belong is strictly speaking undemocratic. 
In this way, the ethnographic method, to paraphrase Battaglia (1999: 118), finds its greater purpose in its struggle against the heavy current of totalizing theories that usually are ideologically driven. I take these young people's motivation at face value and as stemming from a sense of goodwill based on a deeper "Buddhist" understanding of the mutuality of self and other - not straightforward of course in this huge and sometimes bureaucratic organization (something I explore elsewhere in relation to gender practices). This, for some, may invoke connotations of being too sympathetic or apologetic, or lacking in critical insight. This is a particularly contentious issue as the focus is on religious people's successful involvement with organized politics. Politics as a pursuit of power in the state is invariably analysed as a pursuit of self-interest. I have tried to stay true to the way my interlocutors approached their engagement with politics. This means taking young people's religiously inspired desire to create a more humanistic society for real, and to take their political activities to represent attempts to effect change in Japan's particular political world. There is little evidence to the contrary. Illuminating the incompleteness of the picture of Japan as a society that lacks political participation, as a society that has a weak civil society, and that possesses insufficient accountability of political power (e.g. Stockwin, 2008) has been one objective. Moreover, these young people are examples of self-empowerment that results in political change and that hold political representatives accountable. Komeito has been successful in modifying some of the LDP's more extreme policy inclinations. I would argue that this is an example of a "new religion" acting as a secularizing and democratizing force in Japanese society. Rather than religion intruding into the secular domain of politics, religious ideas and practices are here actually creative of secular political subjects who strive for democracy to work. Therefore, Soka Gakkai members do not make up "a huge nonpolitical following that it [Komeito] can count on to mobilise on Election Day and tick the right box," nor is Komeito "essentially a religious party" (Richard Smart, The Japan Times, 25 May, 2010), which nevertheless continue to be the main arguments presented in media and political discourse.

Soka Gakkai is not a collectivist culture, but rather a kind of individualism where one's mental and cultural orientation places self-esteem at the height of one's judgment and that stresses self-reliance or one's own ability to defend that position. However, it is an individualism that fosters the ability to take collective action. We need to move beyond seeing democracy as equalling the political system, and start to include the places and processes by which people participate. While a more macro-level view of politics in Japan is interesting and necessary it will not help cast light on the political participation of youths in this study. The wider conclusions made about democracy based on a deductive, structural analysis

(c) Equinox Publishing Ltd 2011.

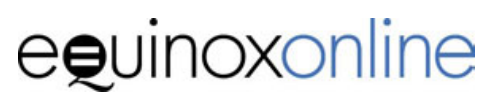


need to be reconsidered to understand that for instance in this case, leadership by election in a religious organization would not necessarily facilitate better democratic practices. In fact, I would argue it would worsen it. By stating this, I do not suggest that we can dismiss as insignificant certain authoritarian aspects of decision-making in Soka Gakkai. However, to view the political activities of Soka Gakkai members as necessarily undemocratic/ unthinking/non-political because they do not elect their religious leaders is to put the cart before the horse and adhere to structural objectvism that explains social behaviour from the point of view of the observer. This may be a valid position but it has to be acknowledged for what it is: an interpretation of motivation that need to be validated by ethnographic investigation.

\section{References}

Abe Hitoshi, Muneyuki Shindo, and Sadafumi Kawato. 1994. The Government and Politics of Japan. Trans. James W. White. Tokyo: University of Tokyo Press.

Battaglia, Deborah. 1999. "Toward an Ethics of the Open Subject: Writing Cultures in Good Conscience," in Henrietta L. Moore ed. Anthropological Theory Today. Cambridge: Polity Press, 114-50.

Burton, John W. 1983. “Answers and Questions: Evans-Prichard on Neuer Religion,” Journal of Religion in Africa, 14.3, 167-86. doi:10.1163/157006683X00068

Christensen, Ray. 2000. Ending the LDP Hegemony: Party Cooperation in Japan. Honolulu: University of Hawai'i Press.

Curtis, Gerald. 1988. The Japanese Way of Politics. New York: Columbia University Press.

Davis, Winston. 1991. "Fundamentalism in Japan: Religious and Political," in Martin E. Marty and R. Scott Appleby eds. Fundamentalism Observed. Chicago; London: University of Chicago Press, 782-813.

Earhart, H. Byron. 1984. Religions of Japan. New York: Harper \& Row.

Eto, Shunsuke, and Wajo Hichiri. 2003. Jiminto - Soka Gakkai - Komeito: Kokumin Fuzai no Renritsu Seiken Hishi [LDP - Soka Gakkai - Komeito: The Secret History of Coalition Government without the People]. Gakushunotomo Press.

Fisker-Nielsen, A. M. Forthcoming. Young Soka Gakkai Youth and Komeito: Religion and Politics in Contemporary Japan. Japan Anthropology Series; Routledge.

Foucault, Michel. 1979. Discipline and Punish: The Birth of the Prison. Trans. Alan Sheridon. Harmondsworth: Penguin Books.

Gellner, David N., and Eric Hirsch. 2001. Inside Organizations: Anthropologists at Work. Oxford: Berg.

Goodman, Roger, and Kirsten Refsing. 1992. Ideology and Practice in Modern Japan. London: Routledge.

Hardacre, Helen. 2003. "After Aum: Religion and Civil Society in Japan," in Frank J. Schwartz and Susan J. Pharr eds. The State of Civil Society in Japan. Cambridge: Cambridge University Press, 135-53.

Hardacre, Helen. 2004. "Religion and Civil Society in Japan," Japanese Journal of Religious Studies, 31.2, 390-415. 
Hardacre, Helen. 2005. “Constitutional Revision and Japanese Religions," Japanese Studies, 25.3 (December), 234-47.

Hoye, Timothy. 1999. Japanese Politics: Fixed and Floating Worlds. New Jersey: Texas Women's University.

Inoguchi, Takashi. 2009. "Political Culture," in Yoshio Sugimoto ed. The Cambridge Companion to Modern Japanese Culture. Cambridge: Cambridge University Press, 166-81.

Inoue, Nobutaka, et al. 1996. Shinshūkyō kyōdan, jinbutsu jiten. Tokyo: Kōdansha.

Ishii, Kenji. 2000. "Nihonjin no ‘shūkyō dantain' ni tai suru ishiki to jittai ni tsuite” [Japanese Attitudes towards Religious Organizations], Chūō chōsahū, 510.4, 1-4.

Johnson, Chalmers. 1995. Japan: Who Governs? The Rise of the Developmental State. New York: W. W. Norton.

Kisala, Robert. 1999. Prophets of Peace: Pacifism and Cultural Identity in Japan's New Religions. Honolulu: University of Hawai'i Press.

Kobayashi, M. 2001. Gakkyū saisei [The Rejuvenation of the Classroom]. Tokyo: Kōdansha.

Kotani, Satoshi. 2004. "Why Are Japanese Youth Today So Passive?" in Gordon Mathews and Bruce White eds. Japan's Changing Generations: Are Young People Creating a New Society? London: RoutledgeCurzon, 31-45.

Kunin, Seth. 2006. “The Dialectical Relationship between Theory and Ethnography," Diskus , 7. www.basr.ac.uk/diskus/diskus7/kunin/htm

Lasswell, Harold Dwight. 1950. Politics: Who Gets What, When, How. New York: Peter Smith.

Lipson, Leslie. 1993. The Great Issues of Politics: An Introduction to Political Science. Englewood Cliffs, NJ: Prentice Hall.

LoBreglio, John. 1997. "Revisions to the Religions Corporations Law: An Introduction and Annotated Translation," Japanese Religions, 22.1, 38-59.

Mathews, Gordon, and Bruce White. 2004. Japan's Changing Generations: Are Young People Creating a New Society? London: Routledge. doi:10.4324/9780203316627

McVeigh, Brian J. 1998. The Nature of the Japanese State: Rationality and Rituality. London, New York: Routledge.

Metraux, Daniel A. 1999. Aum Shinrikyo and Japanese Youth. Lanham, MD: University Press of America.

Murō, Tadashi. 2000. "Shirarezaru Kyōsei Kaishū meguru kōbo" [The Vicissitudes of Forcible Conversions], Tsukuru, 333.3, 136-47.

Nakamaki, Hirochika. 2003. Japanese Religions at Home and Abroad: Anthropological Perspectives. London and New York: RoutledgeCurzon.

Nakane, Chie. 1998 [1970]. Japanese Society. Berkeley, Los Angeles and London: University of California Press.

Nakano, Lynne, and Moeke Wagatsuma. 2004. "Mothers and their Unmarried Daughters," in Gordon Mathews and Bruce White eds. Japan's Changing Generations: Are Young People Creating a New Society? London: RoutledgeCurzon, 137-54.

Ouroussoff, Alexandra. 2001. "What is an Ethnographic Study?" in David N. Gellner and Eric Hirsch eds. Inside Organizations: Anthropologists at Work. Oxford, New York: BERG, 157-82.

Reader, Ian, and George Tanabe. 1998. Practically Religious: Worldly Benefits and the Common Religion of Japan. Honolulu: University of Hawai'i Press.

Reader, Ian. 2005. "Historical, New, and New Religions," in Jennifer Robertson ed. A Companion to the Anthropology of Japan. Malden, USA, and Oxford, UK: Blackwells, 431-51.

Roberts, Glenda S. 2005. "Shifting Contours of Class and Status," in Jennifer Robertson ed. A Companion to the Anthropology of Japan. Malden (USA), Oxford (UK) and Victoria (Australia): Blackwell Publishing, 104-24.

(c) Equinox Publishing Ltd 2011.

\section{equinoxonline}


Sado, Hirano. 2005. Komeito - Soka Gakkai Shinjitsu [The Truth about Komeito - Soka Gakkai]. Kodansha.

Sakurai, Tetsuo. 2004. "The Generation Gap in Japanese Society since the 1960s," in Gordon Mathews and Bruce White eds. Japan's Changing Generations: Are Young People Creating a New Society? London: RoutledgeCurzon, 15-30.

Schaede, Ulrike. 1995. "The Old-boy Network and Government-Business Relations in Japan," Journal of Japanese Studies, 21 (Summer), 293-317. doi:10.2307/133010

Scheiner, Ethan. 2006. Democracy without Competition in Japan: Opposition Failure in a One-Party Dominant State. New York: Cambridge University Press.

Scholte, Bob. 1980. "Anthropological Traditions: Their Definitions," in Stanley Diamond ed. Anthropology: Ancestors and Heirs. The Hague: Mouton Publishers, 53-87.

Shimazono, Susumu. 2004. From Salvation to Spirituality: Popular Religious Movements in Modern Japan. Victoria, Australia: Trans Pacific Press.

Smart, Richard, "Looking East as British System goes South," Japan Times on line, 25 May, 2010 http://search.japantimes.co.jp/cgi-bin/fl20100525zg.html

Stockwin, J. A. A. 2008. Governing Japan: Divided Politics in a Resurgent Economy. Australia: Blackwell, 4th edn.

Van Bremen, Jan. 1995. "Introduction: The Myth of the Secularization of Industrialized Societies," in Jan van Bremen and D. P. Martinez eds. Ceremony and Ritual in Japan. London: Routledge.

Van Wolferen, Karel. 1989.The Enigma of Japanese Power. London: Macmillan.

White, Bruce. 2004. "The Local Roots of Global Citizenship: Generational Change in a Kyushu Hamlet," in Gordon Mathews and Bruce White eds. Japan's Changing Generations; Are Young People Creating a New Society? London: RoutledgeCurzon, ch. 3.

White, James. 1970. The Sōkagakkai and Mass Society. Stanford; Stanford University Press. Yamada, Naoki. 2004. Soka Gakkai to ha Nanika [What is the Soka Gakkai?]. Shinkosha Press. Yuki, Hideo. 1997. "Problems with the Revisions to the Religious Corporations Law," Japanese Religions, 22.1. 